\title{
Nutrient suppression in passion fruit species: an approach to leaf development and morphology
}

Lucas Aparecido Manzani Lisboa ${ }^{1}$; José Carlos Cavichioli ${ }^{2}$; Rodrigo Vitorino²; Paulo Alexandre Monteiro de Figueiredo ${ }^{1}$; Ronaldo da Silva Viana ${ }^{1}$

${ }^{1}$ São Paulo State University (Unesp), College of Agricultural and Technological Sciences, Dracena, Brazil. ${ }^{2}$ Paulista Agribusiness Technology Agency (APTA), Alta Paulista Regional Camp, Adamantina, Brazil. E-mail: lucas.lisboa@unesp.br

\begin{abstract}
The production of passion fruit in commercial areas requires a good correction of nutrients in the soil, however, with nutritional restrictions it can cause symptoms of deficiency expressed mainly in the leaves and stems, which may appear spots, reduced growth, changes in the architecture of these organs mainly in the its size and shape. This work aimed to know the effects caused by the suppression of nutrients in passion fruit species with an approach on their development and leaf morphology. The experimental design was completely randomized (DIC) in a $2 \times 6$ factorial scheme where the first factor was composed of two passion fruit species: $P$. gibertii and $P$. edulis, interacting with the availability of nutrients, that is, a control group with the supply of all nutrients, with nitrogen suppression $(\mathrm{N})$; phosphorus $(\mathrm{P})$; potassium $(\mathrm{K})$; magnesium $(\mathrm{Mg})$ and iron $(\mathrm{Fe})$, totaling 12 treatments with four replications totaling 48 plots or plastic vessels per experiment. The species $P$. edulis showed better responses to the variables of development and leaf morphology. The species $P$. gibertii is more susceptible to nutrient deficiency and showed changes in the color and shape of its leaves with the restriction of nutrients. The nutrients Fe and Mg caused greater restrictions on the development and leaf morphology of passion fruit species. It is necessary to carry out a new study with the species $P$. gibertii regarding the appropriate concentrations of $\mathrm{N}, \mathrm{P}$ and $\mathrm{K}$ provided in planting and cover, as this species is used as a rootstock in commercial areas.
\end{abstract}

Keywords: Passiflora gibertii; Passiflora edulis; plant nutrition; plant morphology.

\section{Supressão de nutrientes em espécies de maracujazeiro: uma abordagem no desenvolvimento e na} morfologia foliar

\section{Resumo}

A produção de maracujá em áreas comerciais demanda de uma boa correção de nutrientes no solo, no entanto, com restrições nutricionais pode provocar sintomas de deficiência expressada principalmente nas folhas e caule, podendo aparecer manchas, redução no crescimento, mudança na arquitetura desses órgãos principalmente no seu tamanho e formato. Esse trabalho teve por objetivo conhecer os efeitos provocados pela supressão de nutrientes em espécies de maracujazeiros com uma abordagem no seu desenvolvimento e na morfologia foliar. $O$ delineamento experimental foi inteiramente casualizado (DIC) em esquema fatorial $2 \times 6$ onde o primeiro fator foi composto por duas espécies de maracujazeiros sendo elas: $P$. gibertii e $P$. edulis, interagindo com a disponibilidade de nutrientes, ou seja, um grupo controle com o fornecimento de todos os nutrientes, com as supressões de nitrogênio $(N)$; fósforo $(P)$; potássio $(K)$; magnésio $(\mathrm{Mg})$ e ferro $(\mathrm{Fe})$, totalizando 12 tratamentos com quatro repetições totalizando 48 parcelas ou vasos plásticos por experimento. A espécie $P$. edulis apresentou melhores respostas para as variáveis de desenvolvimento e morfologia foliar. A espécie $P$. gibertii é mais susceptível a deficiência de nutrientes e apresentou mudanças na coloração e formato das suas folhas com a restrição de nutrientes. Os nutrientes Fe e Mg causaram maiores restrições no desenvolvimento e na morfologia foliar das espécies de maracujá. É necessário realizar novo estudo com a espécie $P$. gibertii quanto às concentrações adequadas de $N, P$ e K fornecidas no plantio e cobertura, pois essa espécie é utilizada como porta enxerto em áreas comerciais.

Palavras-chave: Passiflora giberti; Passiflora edulis; nutrição de plantas; morfologia vegetal. 


\section{Introduction}

Passion fruit belonging to the Passifloraceae family has two species of highlights such as Passiflora gibertii N.E. Brown native Brazilian used as a rootstock for the species Passiflora edulis Sims or yellow passion fruit, has a greater economic interest, as it is widely used in the production of juices in the food industry due to its performance and has vitamin $C$ in its composition. The quality of the seedling is fundamental to increase the productivity of the orchards and the precocious production of the passion fruit. In this way, correct fertilization will contribute to the nutritional status of the plant and obtain good quality plants (PRADO et al., 2005). However, the practice of fertilization must require knowledge about the morph-physiological characteristics of the plant, in addition to those related to the availability of nutrients in the soil and its behavior in the plant (ALMEIDA et al., 2006).

Its production in commercial areas demands a good correction of nutrients in the soil, in order to guarantee the highest fruit productivity, however, the passion fruit can suffer nutritional restrictions, which can cause symptoms of deficiency expressed in different organs of the vegetable, mainly on the leaves and stem, stains may appear, growth restriction and even change in the architecture of these organs, mainly reduction in their size and shape, the restriction of nitrogen $(\mathrm{N})$ can reduce the synthesis of proteins in the plant organism. $\mathrm{N}$ deficiency decreases the capacity of metabolic sources and drains, reducing the formation of photosynthetic components and shortening the average leaf life and the leaf area index (MOHOTTI; LOWLOR, 2002; QIN et al., 2019; WANG et al., 2019).

Phosphorus $(P)$ is another nutrient that stands out in the development of the plant, as it acts in the process of cell respiration, photosynthesis, gene expression, cell division and sugar formation. In addition to stimulating the initial stages of formation of the root system, ensuring greater absorption of other nutrients (TAIZ; ZEIGER, 2013). The contact of the phosphorus with the roots occurs mainly through the diffusion process and, in this case, the extension of the root system is extremely important so that greater amounts of phosphorus can be absorbed due to root interception and in addition to contributing to the formation of a system healthy and well-formed root system, helps a lot in the sprouting (FLEISCHER et al., 2019).

On the other hand, potassium $(K)$ is essential in osmotic regulation, stomatal mechanism, photosynthesis, enzymatic activation and meristematic growth. Its deficiency reduces the elaboration and translocation of carbohydrates and inhibits the accumulation of protein nitrogen in the leaves (SRIVASTAVA et al., 2020). Under the lack of this nutrient there is an increase in the respiratory rate, which consequently arises a greater demand in the consumption of sugars, which leads to a decrease in the accumulation of carbohydrates, which may cause less growth of the vegetable (SHEN et al., 2019). In this situation, potassium is redistributed from the oldest to the youngest regions, causing chlorotic stains in the leaf and a purplish color in the central vein of the leaves, which in more extreme situations can even dry the leaf ends (GUO et al., 2019).

Another important nutrient for vegetables is magnesium $(\mathrm{Mg})$, because ribosome organelles are a highly required element, including for the formation of the RNA polymerase enzyme, essential for protein synthesis to occur (SHAUL, 2002). Likewise, magnesium is a key part of photosynthesis where in the chlorophyll molecule this nutrient has an important structural role, as it is positioned as a central atom. In another phase of photosynthesis, biochemistry, atmospheric carbon dioxide is incorporated into a carbohydrate formed by five carbons, called ribulose-1,5-bisphosphate, so that later glucose is made. For this, it is necessary for the activation by magnesium of the enzyme rubisco, or ribulose bisphosphate carboxylase oxygenase, also present in chloroplasts (TAIZ; ZEIGER, 2013). Also in chloroplasts, in the specific places that house chlorophyll, high concentrations of magnesium are required to maintain $\mathrm{pH}$ and balance of loads ( $\mathrm{KOCH}$ et al., 2019). Magnesium deficiency can, therefore, cause changes in their size, structure and functioning, in addition to causing starch accumulation, damaging, in general, the photosynthetic process (PRANCKIETIENE et al., 2020).

Plants absorb iron (Fe) in the form of ferrous ion $\mathrm{Fe}^{2+}$, in plants, its deficiency induces plants to excrete amino acids into the rhizosphere, the outer peripheral region of the 
roots, thus forming stable complexes, which allows the transport of iron protected into the tissues (KOBAYASHI et al., 2019). That is why plants differ from each other in their absorption efficiency. Many of these form cytochromes, compounds involved in electron transfer during photosynthesis or cellular respiration, phenomena that occur, respectively, in chloroplasts and mitochondria organelles. As an example, ferredoxin, which, as its name indicates, has iron in its composition (TAIZ; ZEIGER, 2013).

This work aimed to know the effects caused by the suppression of nutrients in passion fruit species with an approach on leaf morphology and its development.

\section{Material and Methods}

Growth conditions and experimental design

In August 2019, an experiment was conducted in the Chemistry laboratory of the Educational Foundation of Andradina, located in Andradina - SP, with artificial light 24 hours with an intensity of $1000 \mu \mathrm{mol} \mathrm{m} \mathrm{m}^{-1} \mathrm{~s}^{-1}$. The experimental design was completely randomized (DIC) in a $2 \times 6$ factorial scheme where the first factor was composed of two passion fruit species: $P$. gibertii and $P$. edulis, interacting with the availability of nutrients, that is, a control group with the supply of all nutrients, with nitrogen suppression (N); phosphorus (P); potassium (K); magnesium (Mg) and iron (Fe), totaling 12 treatments with four replications totaling 48 plots or plastic vessels per experiment. Each plot consisted of seedlings that were obtained in a commercial nursery in the region of the municipality of Adamantina, State of São Paulo and had an average size of $15 \pm 3 \mathrm{~cm}$; with $5 \pm 1$ definitive leaves and aged 20 days.

The seedlings were grown in a nutrient solution with all nutrients for seven days for adaptation. The concentrations of each nutrient where it was applied: $0.75 \mathrm{~g} \mathrm{~L}^{-1}$ of $\mathrm{Ca}\left(\mathrm{NO}_{3}\right)_{2} ; 0.53$ $\mathrm{g} \mathrm{L}^{-1}$ of $\mathrm{KCl} ; 0.15 \mathrm{~g} \mathrm{~L}^{-1}$ of $\mathrm{P}_{2} \mathrm{O}_{5}+\mathrm{Ca}$; $0.4 \mathrm{~g} \mathrm{~L}^{-1}$ of $\mathrm{MgSO}_{4} ; 1.5 \times 10^{-2} \mathrm{~g} \mathrm{~L}^{-1}$ of $\mathrm{CuSO}_{4} ; 2.0 \times 10^{-2} \mathrm{~g} \mathrm{~L}^{-1}$ of $\mathrm{ZnSO}_{4} ; 1.5 \times 10^{-1} \mathrm{~g} \mathrm{~L}^{-1}$ of $\mathrm{MnSO}_{4} ; 1.5 \times 10^{-1}$ of $\mathrm{H}_{3} \mathrm{BO}_{3}$; $1.5 \times 10^{-2} \mathrm{~g} \mathrm{~L}^{-1}$ of $\mathrm{Na}_{2} \mathrm{MoO}_{4} ; 3.0 \mathrm{~g} \mathrm{~L}^{-1}$ of EDTA+Fe (6\%) (FURLANI, 1998), with an electrical conductivity adjusted daily to $2,000 \mu \mathrm{S}$, with a $\mathrm{pH}$ of $6.4 \pm 2$ and after the adaptation period the nutrients were removed according to the treatments.

\section{Leaf histology}

30 days after the beginning of the experiment, a fragment of the first fully expanded leaf was collected from the apex of each plant. All fragments received the procedures relevant to dehydration, diaphanization, inclusion and packaging, and with the aid of a microtome, $10.0 \mu \mathrm{m}$ cross sections were made in each tissue fragment, where they were stained with safranin. The slides were observed in an optical microscope with a camera attached to perform measurements of histological variables using an image program, calibrated with a microscopic ruler at the same magnification, where the following tissues were measured: xylem diameter (XD); phloem diameter (PD); abaxial epidermis thickness (ABET); adaxial epidermis thickness (ADET) and thickness of the palicadic parenchyma (TPP) (REIS et al., 2017). For all variables, ten measurements were made per slide, totaling 40 measurements per treatment.

\section{Development parameter}

On the same occasion, the dry mass air part (DMAP) and dry mass root (DMR) which were obtained by drying in a circulation oven and renewing air at a constant temperature of $65^{\circ} \mathrm{C}$ until they reached constant weight.

\section{Statistical analysis}

For statistical evaluation, the variables were subjected to normality tests where the Shapiro-Wilk test was used, after meeting the test precepts, the analysis of variance was performed using the $F$ test $(p<0.05)$ and their means compared by the Tukey test at $5 \%$ probability (BANZATTO; KRONKA, 2013), a Pearson correlation was also made and the statistical program was used RStudio (R CORE TEAM, 2015).

\section{Results}

A significant difference was observed between the factors in isolation for the variable dry mass air part (DMAP) as shown in Table 1. 
Table 1. Statistical analysis of dry mass air part (DMAP); dry mass root (DMR); xylem diameter (XD) and phloem diameter (PD) of passion fruit species after nutrient suppression in the initial phase of the crop.

\begin{tabular}{lllll}
\hline & $\mathrm{DMAP}(\mathrm{g})$ & $\mathrm{DMR}(\mathrm{g})$ & $\mathrm{XD}(\mu \mathrm{m})$ & $\mathrm{PD}(\mu \mathrm{m})$ \\
\hline$p$ value of Species $(\mathrm{S})$ & $0.0115^{*}$ & $0.5139 \mathrm{Ns}$ & $0.0020^{* *}$ & $0.0001^{* *}$ \\
$p$ value of Nutriente $(\mathrm{N})$ & $0.0001^{* *}$ & $0.0001^{* *}$ & $0.0001^{* *}$ & $0.5155 \mathrm{Ns}$ \\
$p$ value of SxN & $0.0558 \mathrm{Ns}$ & $0.0001^{* *}$ & $0.0054^{* *}$ & $0.2415 \mathrm{Ns}$ \\
OA & 0.62 & 0.18 & 14.00 & 4.08 \\
CV $(\%)$ & 26.52 & 21.37 & 16.32 & 26.92 \\
\hline
\end{tabular}

**significant at the $1 \%$ probability level $(p<0.01)$; *significant at the $5 \%$ probability level $(0.01=<p<0.05)$; Ns-not significant ( $p>=0.05$ ); OA: overall average; CV: coefficient of variation.

The species $P$. gibertii presented a greater dry mass air part (DMAP) with approximately
$19.11 \%$ superior to the species $P$. edulis as demonstrated in Figure 1.

Figure 1. Dry mass air part (DMAP) of passion fruit species after nutrient suppression. The means followed by the same letter do not differ statistically. The Tukey test was applied at the level of 5\% probability. SMD: Significant minimum difference.

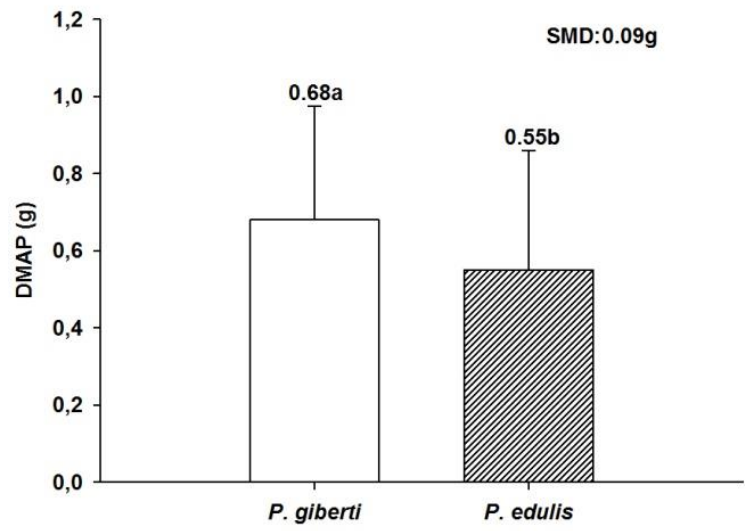

The restriction of the nutrients nitrogen and iron were the ones that caused less deposition of dry mass air part (DMAP) which showed a reduction of approximately $62.74 \mathrm{e}$ $66.66 \%$ respectively, as demonstrated in Figure 2.

Figure 2. Dry mass air part (DMAP) after nutrient suppression in passion fruit species. The means followed by the same letter do not differ statistically. The Tukey test was applied at the level of 5\% probability. SMD: Significant minimum difference.

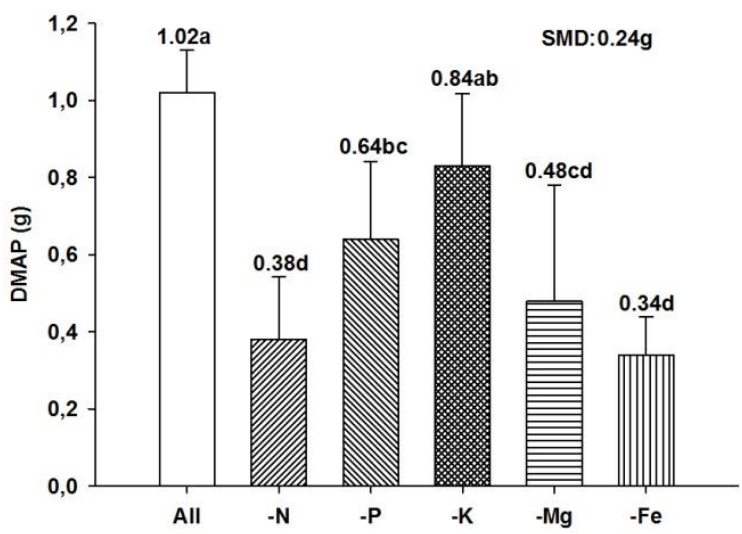


The expression of nutrient deficiencies was expected in the two passion fruit species, but deficiencies were only observed with the naked eye in the $P$. gibertii species, where the nutrient requirements led to changes in the color of the leaves as shown in Figure 3 and there was also a change in the shape of the leaves where the leaf lobes became more rounded and smaller with the suppression of $\mathrm{P}$ and $\mathrm{K}$.

Figure 3. Passiflora gibertii species with nutrient suppression. Bar $=5.0 \mathrm{~cm}$.

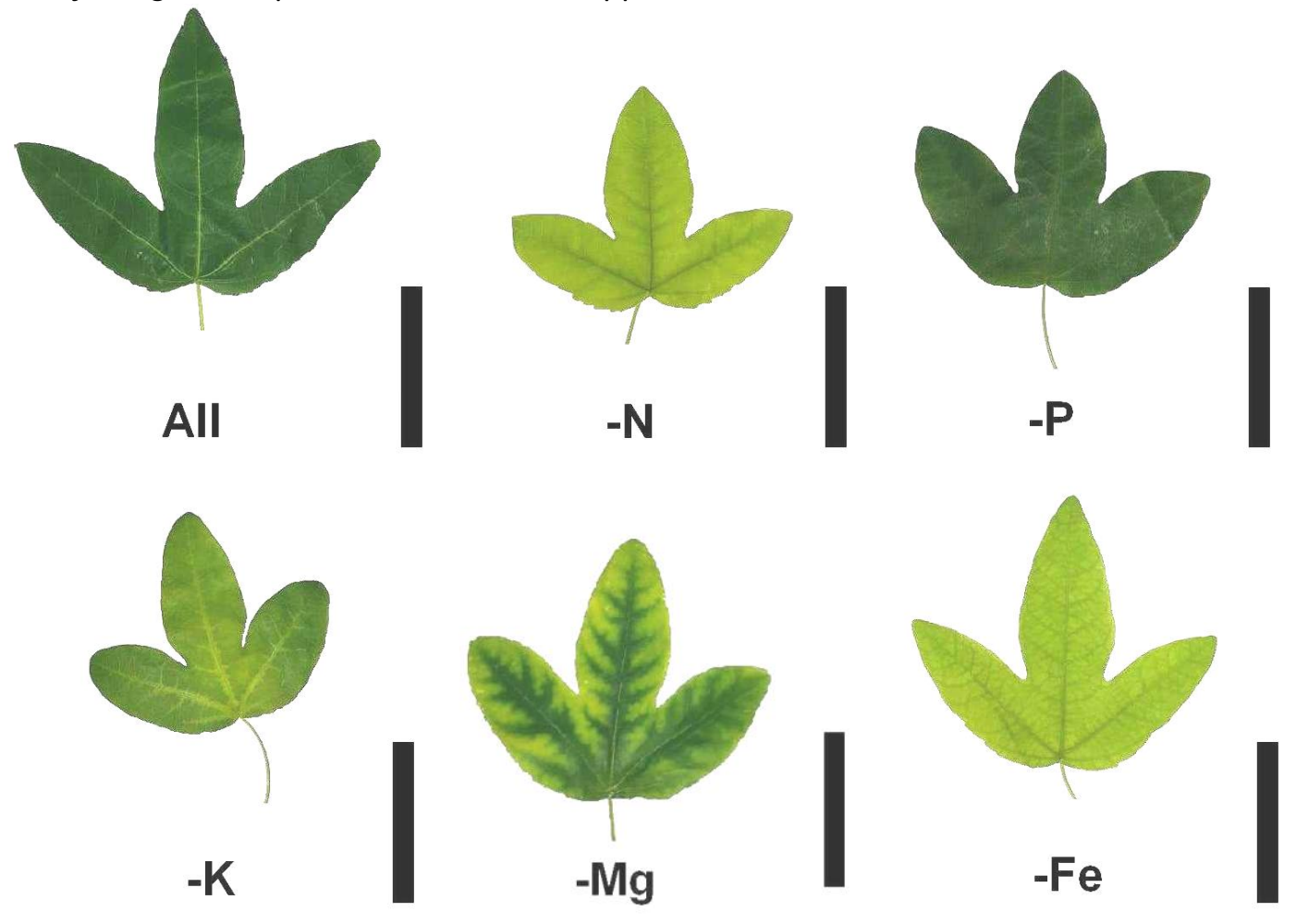

The species $P$. gibertii had the lowest dry mass root (DMR) when the Fe nutrient was suppressed, this restriction caused a reduction of approximately $77.77 \%$ in relation to the treatment with all nutrients, whereas this deleterious effect was not observed in the species $P$. edulis as observed in Table 2 .

Table 2. Unfolding of the interaction of the mean values of the dry mass root (DMR) variable of passion fruit species after nutrient suppression.

\begin{tabular}{ccccccc}
\hline & All & $-\mathrm{N}$ & $-\mathrm{P}$ & $-\mathrm{K}$ & $-\mathrm{Mg}$ & $-\mathrm{Fe}$ \\
\hline$P$. gibertii & $0.27 \mathrm{aAB}$ & $0.13 \mathrm{aCD}$ & $0.15 \mathrm{aCD}$ & $0.29 \mathrm{aA}$ & $0.20 \mathrm{aBC}$ & $0.08 \mathrm{bD}$ \\
P. edulis & $0.21 \mathrm{bA}$ & $0.18 \mathrm{aA}$ & $0.17 \mathrm{aA}$ & $0.15 \mathrm{bA}$ & $0.21 \mathrm{aA}$ & $0.17 \mathrm{aA}$ \\
\hline & \multicolumn{3}{c}{ SMDlin: 0.08} & & & SMDcol: 0.05 \\
\hline
\end{tabular}

The means followed by the same lower case letter in the column do not differ statistically. The means followed by the same capital letter on the line do not differ statistically. The Tukey test was applied at the level of $5 \%$ probability. SMD: Significant minimum difference.

Again, the suppression of the nutrient $\mathrm{Fe}$ in the species $P$. gibertii was the one with the lowest xylem diameter (XD) with approximately $62.11 \%$ in relation to the treatment with all nutrients, while in the species $P$. edulis the absence of nitrogen was the one that showed the lowest mean value with $24.57 \%$ in relation to the control treatment as shown in Table 3. 
Table 3. Unfolding of the interaction of the average values of the variable xylem diameter (XD) of the passion fruit species after nutrient suppression.

\begin{tabular}{|c|c|c|c|c|c|c|}
\hline & All & $-\mathrm{N}$ & $-P$ & $-K$ & $-M g$ & $-\mathrm{Fe}$ \\
\hline P. gibertii & $17.34 \mathrm{aA}$ & $12.01 \mathrm{aB}$ & $11.18 \mathrm{bBC}$ & $14.68 \mathrm{aAB}$ & $15.60 \mathrm{aAB}$ & $6.57 \mathrm{bC}$ \\
\hline P. edulis & 18.39aA & 13.87aA & 14.86aA & 14.06aA & 14.93aA & 14.48aA \\
\hline
\end{tabular}

The means followed by the same lower case letter in the column do not differ statistically. The means followed by the same capital letter on the line do not differ statistically. The Tukey test was applied at the level of $5 \%$ probability. SMD: Significant minimum difference.

This interaction was not found for the variable phloem diameter (PD), where only the passion fruit species that showed a statistical difference between them (Table 1), this difference can be well elucidated in Figure 4, highlighting the species $P$. edulis with $29.49 \%$ higher than the species $P$. gibertii.

Figure 4. Mean values of the phloem diameter (PD) of passion fruit species after nutrient suppression. The means followed by the same letter do not differ statistically. The Tukey test was applied at the level of $5 \%$ probability. SMD: Significant minimum difference.

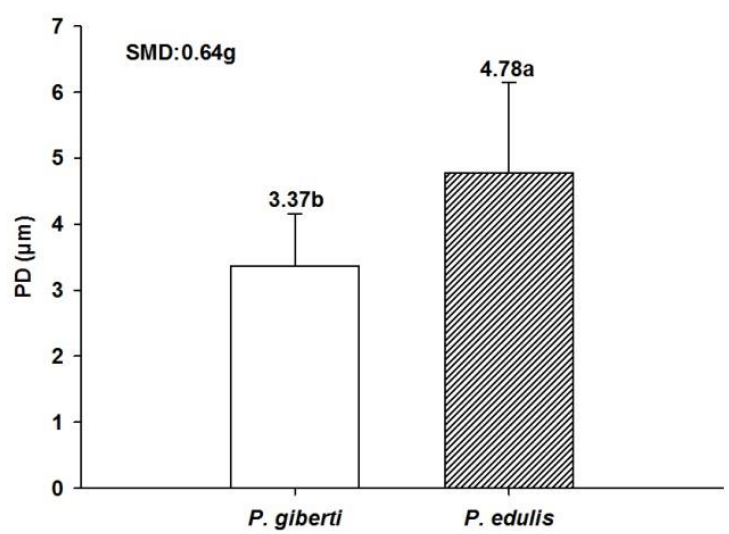

Table 4. Statistical analysis of abaxial epidermis thickness (ABET); adaxial epidermis thickness (ADET) and thickness of the palicadic parenchyma (TPP) of passion fruit species after nutrient suppression in the initial phase of the culture.

\begin{tabular}{llll}
\hline & ABET $(\mu \mathrm{m})$ & ADET $(\mu \mathrm{m})$ & TPP $(\mu \mathrm{m})$ \\
\hline$p$ value of Species $(\mathrm{S})$ & $0.0001^{* *}$ & $0.0001^{* *}$ & $0.0089^{* *}$ \\
$p$ value of Nutriente $(\mathrm{N})$ & $0.0001^{* *}$ & $0.0001^{* *}$ & $0.0001^{* *}$ \\
$p$ value of SxN & $0.0005^{* *}$ & $0.3436 \mathrm{Ns}$ & $0.3410 \mathrm{Ns}$ \\
OA & 7.15 & 7.97 & 20.69 \\
$\mathrm{CV}(\%)$ & 17.62 & 28.85 & 19.66 \\
\hline
\end{tabular}

** significant at the $1 \%$ probability level $(p<0.01) ;{ }^{*}$ significant at the $5 \%$ probability level $(0.01=<p<0.05)$; Ns not significant ( $p>=0.05) ; O A$ : overall average; $C V$ : coefficient of variation.

An interaction was observed between the factors in the variable abaxial epidermis thickness (ABET) as noted in Table 4.

With the suppression of nutrients for the species $P$. gibertii a abaxial epidermis thickness (ABET) presented lower mean values, where the absence of Fe was the cause of this reduction in a more marked way, then $\mathrm{Mg}, \mathrm{K}, \mathrm{N}$ and finally $\mathrm{P}$. While in the species $P$. edulis the lack of nutrients $\mathrm{K}$ and $\mathrm{Fe}$ were the elements which led to the lowest development of ABET, with approximately 36.95 and $36.40 \%$ respectively as shown in Table 5. 
Table 5. Unfolding of the interaction of the abaxial epidermis thickness (ABET) variable of passion fruit species after nutrient suppression.

\begin{tabular}{|c|c|c|c|c|c|c|}
\hline & All & $-\mathrm{N}$ & $-P$ & $-K$ & $-M g$ & $-\mathrm{Fe}$ \\
\hline P. gibertii & $12.14 \mathrm{aA}$ & $5.47 \mathrm{bB}$ & $5.85 a B$ & $4.61 \mathrm{bB}$ & $4.00 \mathrm{bB}$ & $3.38 \mathrm{bB}$ \\
\hline P. edulis & $10.85 \mathrm{aA}$ & $10.24 a A B$ & $7.65 \mathrm{aBC}$ & $6.84 \mathrm{aC}$ & 7.92aBC & $6.90 \mathrm{aC}$ \\
\hline
\end{tabular}

The means followed by the same lower case letter in the column do not differ statistically. The means followed by the same capital letter on the line do not differ statistically. The Tukey test was applied at the level of 5\% probability. SMD: Significant minimum difference.

For the variable adaxial epidermis thickness (ADET) the species $P$. edulis presented a higher mean value with a difference of approximately $47.02 \%$ in relation to the species P. gibertii, as shown in Figure 5.

Figure 5. Average values of the adaxial epidermis thickness (ADET) of passion fruit species after nutrient suppression. The means followed by the same letter do not differ statistically. The Tukey test was applied at the level of $5 \%$ probability. SMD: Significant minimum difference.

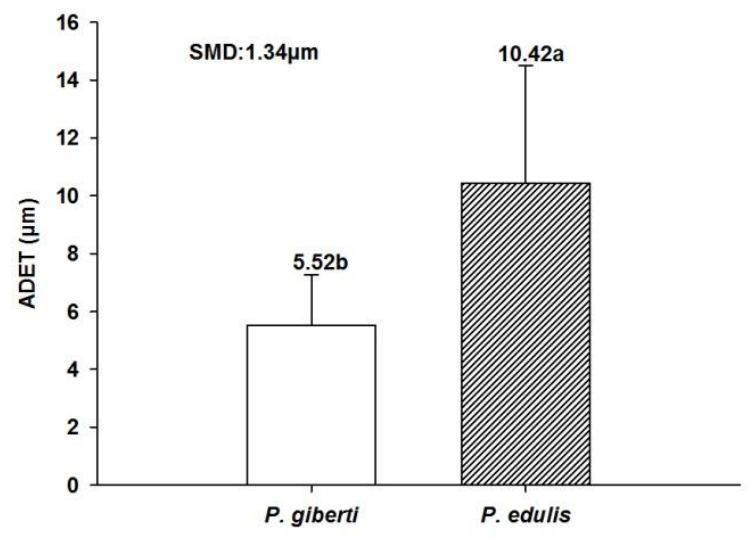

The deletions of nutrients caused a reduction in the ADET variable as shown in Figure 6. It is worth mentioning for this deleterious effect in the absence of the elements $\mathrm{Fe}$ and $\mathrm{Mg}$ with approximately 53.10 and $47.92 \%$ respectively in relation to the treatment that received all nutrients. 
Figure 6. Average values of the adaxial epidermis thickness (ADET) of passion fruit species after nutrient suppression. The means followed by the same letter do not differ statistically. The Tukey test was applied at the level of $5 \%$ probability. SMD: Significant minimum difference.

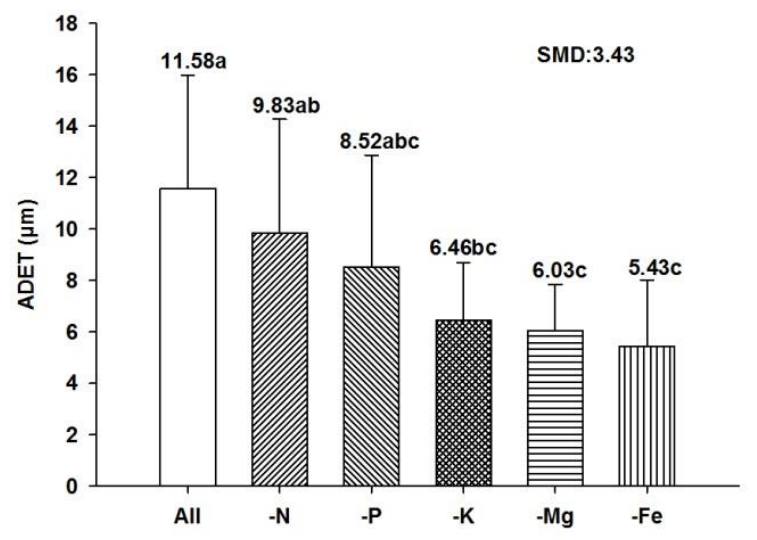

For the variable thickness palicadic parenchyma (TPP) the species $P$. gibertii had the highest average value, with a difference of approximately $14.60 \%$ in relation to the species P. edulis as shown in Figure 7.

Figure 7. Average values of the thickness palicadic parenchyma (TPP) of passion fruit species after nutrient suppression. The means followed by the same letter do not differ statistically. The Tukey test was applied at the level of $5 \%$ probability. SMD: Significant minimum difference.

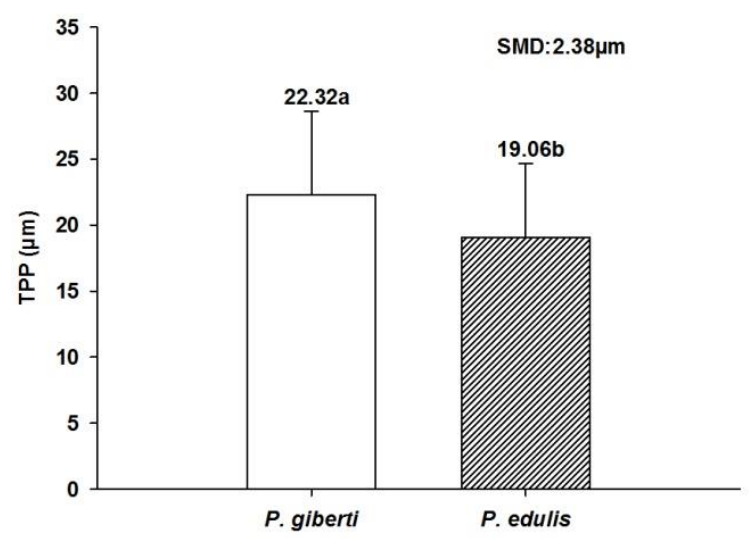

Again, the suppression of nutrients Fe, $\mathrm{Mg}$ and $\mathrm{N}$ were the ones that presented the lowest averages in the variable thickness palicadic parenchyma (TPP) as shown in Figure 8.
This restriction led to a reduction of approximately $43.28 ; \quad 38.60$ and $38.57 \%$ respectively. 
Figure 8. Average values of the thickness palicadic parenchyma (TPP) after nutrient suppression of passion fruit species. The means followed by the same letter do not differ statistically. The Tukey test was applied at the level of $5 \%$ probability. SMD: Significant minimum difference.

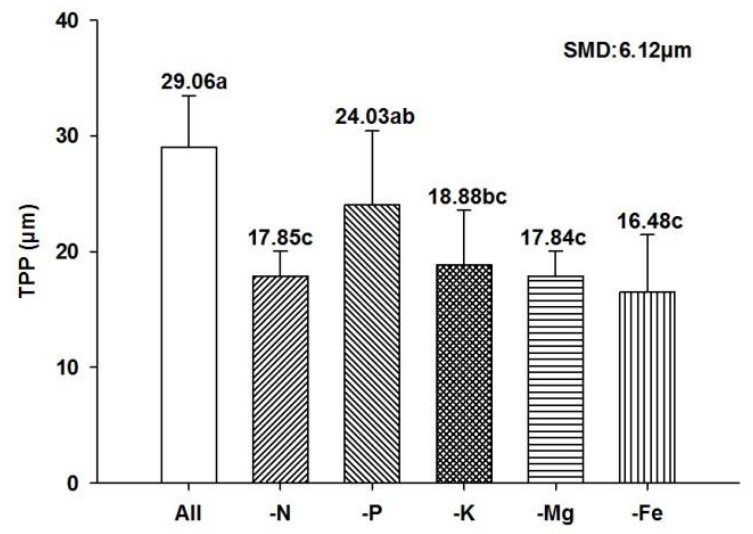

Figure 9 shows the significant Pearson correlations between the variables analyzed in the passion fruit species after nutrient suppression. Highlighting the positive linear interactions between dry mass air part (DMAP) with the dry mass root (DMR); xylem diameter (XD) and thickness palicadic parenchyma (TPP); in the same way the interaction between dry mass root (DMR) with the xylem diameter (XD) and thickness palicadic parenchyma (TPP); also between xylem diameter (XD) with phloem diameter (PD); abaxial epidermis thickness (ABET) and adaxial epidermis thickness (ADET), besides phloem diameter (PD) with abaxial epidermis thickness (ABET) and lastly the interactions of abaxial epidermis thickness (ABET) with adaxial epidermis thickness (ADET) and thickness palicadic parenchyma (TPP).

Table 6 shows the matrices of significant linear regressions of Pearson's interactions of the variables analyzed in passion fruit species after nutrient suppression.

Figure 9. Pearson's correlation between the variables analyzed in the passion fruit species after nutrient suppression. DMAP - Dry mass air part; DMR - Dry mass root; XD - Xylem diameter; PD - Phloem diameter; ABET - Abaxial epidermis thickness; ADET - Adaxial epidermis thickness, TPP - Thickness of the palicadic parenchyma.

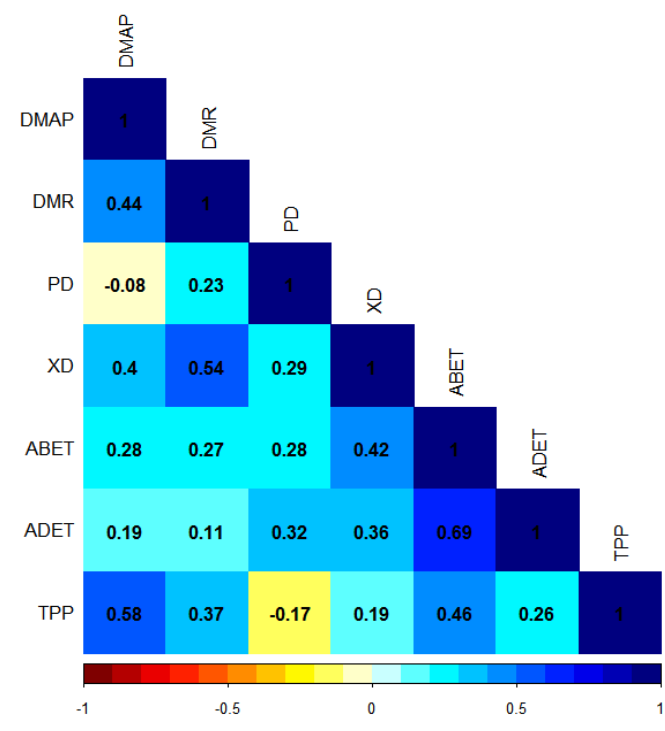


Table 6. Matrix of significant linear regressions of Pearson interactions of the variables analyzed in passion fruit species after nutrient suppression.

\begin{tabular}{llll}
\hline \multicolumn{1}{c}{$\mathrm{Y}=\beta \mathrm{O}+\beta \mathrm{il}+\ldots+\beta \mathrm{nN}$} & $\mathrm{F}$ & $\mathrm{R}^{2}$ \\
\hline DMAP $(\mathrm{g})$ & $\mathrm{DMAP}=0.23650392+2.04475036 \mathrm{DMR}$ & $10.94^{* *}$ & 0.1921 \\
& $\mathrm{DMAP}=0.14202958+0.03427114 \mathrm{XD}$ & $8.74^{* *}$ & 0.1597 \\
& $\mathrm{DMAP}=0.02257451+0.02895887 \mathrm{TPP}$ & $23.40^{* *}$ & 0.3372 \\
$\mathrm{DMR}(\mathrm{g})$ & $\mathrm{DMR}=0.04905885+0.00995651 \mathrm{XD}$ & $19.20^{* *}$ & 0.2934 \\
& $\mathrm{DMR}=0.10635888+0.00396728 \mathrm{TPP}$ & $7.35^{* *}$ & 0.1377 \\
$\mathrm{XD}(\mu \mathrm{m})$ & $\mathrm{XD}=10.7663254+0.79277155 \mathrm{PD}$ & $4.30^{*}$ & 0.0854 \\
& $\mathrm{XD}=10.2681930+0.52147022 \mathrm{ABET}$ & $10.05^{* *}$ & 0.1793 \\
& $\mathrm{XD}=11.4012464+0.32588188 \mathrm{ADET}$ & $7.01^{*}$ & 0.1322 \\
$\mathrm{PD}(\mu \mathrm{m})$ & $\mathrm{PD}=3.23230751+0.10626597$ ADET & $5.31^{*}$ & 0.1034 \\
$\mathrm{ABET}(\mu \mathrm{m})$ & $\mathrm{ABET}=3.14189624+0.50344471 \mathrm{ADET}$ & $42.21^{* *}$ & 0.4785 \\
& $\mathrm{ABET}=2.61978449+0.21929524 \mathrm{TPP}$ & $12.64 * *$ & 0.2156 \\
\hline
\end{tabular}

DMAP - Dry mass air part; DMR - Dry mass root; XD - Xylem diameter; PD - Phloem diameter; ABET - Abaxial epidermis thickness; ADET - Adaxial epidermis thickness, TPP - Thickness of the palicadic parenchyma.

\section{Discussion}

Both in the species $P$. gibertii and $P$. edulis, the suppression of $\mathrm{N}$ caused a reduction in the development of the plant area, since this macronutrient is the one that demands greater attention in planting fertilization or cover, as this nutrient is part of the structure of the plants. main proteins and nitrogenous bases. Another highlight is the element $P$ that is present in the composition of membranes, energy molecules and also acts as a signal in the mechanisms of cellular homeostasis through the activation of the PSI gene groups that act directly in the plant physiology (QIN et al., 2019; WANG et al., 2018; HAM et al., 2018; SANTOS et al., 2018).

It is worth mentioning that the deficiency of $\mathrm{N}$ causes a general yellowing of the leaves (Figure 3), as this element is part of the structure of chlorophylls, where its deficiency reduces the photosynthetic rate of the plant, which, consequently, its development has become compromised as seen in Figure 2. And even in the roots, $\mathrm{N}$ acts directly in signaling the stem cells of caliptrogen that start to influence the root architecture of plants through the absorption of $\mathrm{NO}^{-3}$ from the soil solution, with the deficiency of this nutrient caused a lower dry root mass (Table 2) and also caused a reduction in the xylem development (Table 3) (WANG et al., 2019), which has the function of transporting water and nutrients absorbed from the soil to the aerial part of the plant, which shows the interaction between these two DMR variables $\mathrm{X}$ XD (Table 6 and Figure 9). That in turn its development has been compromised, where nitrogen suppression may have directly impaired cofactor activity as a catalyst in the last step of the action of enzymes in the lignin biosynthesis and that this biomolecule plays a role in the cell wall composition that causes its hardening increasing its resistance to mechanical damage, therefore, the compromised internal structure of the pot may have caused a reduction in the development of the aerial part of the passion fruit, especially in the shape of the leaves (Figure 3) (QIN et al., 2019).

It is worth mentioning that the conducting vessels are directly linked to the efficiency of the photosynthetic rate of the plant, since the leaves require a large amount of water at the oxygen reaction sites in photosystem 2 (PSII) and nutrients as cofactors of biochemical reactions (STEWART et al., 2017) and when there is a reduction in the availability of water, your entire metabolism is impaired.

Even though no statistical difference was observed with the nutrient $K$, it is worth mentioning that this element is important in the homeostasis of the membranes of the mesophyll cells of the leaves of Camellia sinensis ((L.) $\mathrm{O}$. Kuntze) when the plants were subjected to water stress (ZHANG et al., 2019), where the $\mathrm{H}^{+}$-ATPase causes an efflux of $K$ out of the cells with the lack of water, that after its rehydration the $\mathrm{H}^{+}$-ATPase guaranteed a membrane hyperpolarization and that for consequently a minor loses $\mathrm{K}$.

These reactions can be well observed in the activities of opening and closing the leaf stomata (WOLDEMARIAM et al., 2018), another function of $\mathrm{K}$ together with $\mathrm{Mg}$, is to act directly in the transport of photoassimilates mainly of sucrose from the cells of the palisade 
parenchyma to the apoplast (Table 4 and Figure 7) (KOCH et al., 2019) which are directed to the phloem pots and directed to the other regions of the plant and which can also guarantee greater sweetness of the fruits of the species $P$. edulis at the time of harvest and a well-nourished plant produces fruits with longer shelf life (PACHECO et al., 2018).

The color change of the leaves due to the suppression of $\mathrm{Mg}$ is related to its importance in the composition of the chlorophyll molecule, mainly of the PSII photosystem, the leaves have intense yellowish spots between the main veins (Figure 3). It is worth mentioning that with the cultivation under restriction of this nutrient, it allows an increase of $\mathrm{H}_{2} \mathrm{O}_{2}$ in plants under stress (SAMBORSKA et al., 2018), where Mg acts as a cofactor for enzymes such as ATPase, protein kinases, phosphatases, carboxylases and superoxide dismutase (SOD), the which explains the elevation of $\mathrm{H}_{2} \mathrm{O}_{2}$, since SOD did not perform its function efficiently.

Due to the toxic nature of $\mathrm{H}_{2} \mathrm{O}_{2}$ and the possible increase in the internal concentration of cells, mainly in the palisade parenchyma, as they are cells rich in chloroplasts, where in this tissue they perform photosynthesis as the greatest intensity, their structures may have been unstructured and their physiological functions have become be compromised (REIS et al., 2017), which implied a reduction in the development of the plant mainly in the production of dry mass (Figure 2 and Table 1).

The species $P$. gibertii is used as a rootstock for the species $P$. edulis, thus making it necessary to pay more attention to producers regarding the management of this species in the field, as it demonstrates that $P$. gibertii is more sensitive to nutrient deficiency and to the choice of areas with soil with better chemical attributes and a well-adjusted fertilization makes it an important factor for the good development of this species. Thus, the cultivation of Passiflora sp. in hypoferric soils it can generate a demand for foliar fertilization of the micronutrient $\mathrm{Fe}$, which increases the production costs of the crop.

The reduction in the dry mass of the area caused by the suppression of $\mathrm{Fe}$ in both species of passion fruit (Figure 2 and Table 3 ), may have occurred due to the importance of this element as an electron donor for ferrodoxin in the photosynthetic apparatus of the chloroplasts present in the palisade parenchyma of the leaves of vegetables (TAIZ; ZEIGER, 2013; SCHORSCH et al., 2018; SCHULLER et al., 2019), which may have caused a reduction in the production of NADH + which will later be used in carbon fixation in the Calvin cycle which, consequently, less dry mass deposition (AMTHOR et al., 2019), considering that even when the plant is under oxidative stress, Fe acts as a reaction cofactor for the FeSOD enzyme that is directly linked to the maintenance of the palisade parenchyma chloroplasts (ALSCHER et al., 2002), with this physiological breakdown its development started to be impaired, similarly to the nutrient $\mathrm{Mg}$, as these nutrients have metallic properties and perform the function of electron donors to occur these chemical reactions.

With the changes in the internal morphology of the leaf, mainly of the palisade parenchyma (Figure 7 and 8), it may have led to a reduction in the adaxial and abaxial epidermis, as the development was compromised, showing that the suppression of nutrients may lead the plants to exposure to diseases and even the loss of water due to transpiration, since the epidermis are directly linked to the protection of plants against these external agents due to the reduction of epidermis (CASTRO et al., 2009). These responses corroborate the positive interactions found between these variables (Table 6 and Figure 9). There is a difference in the development and response to the suppression of nutrients between species, given that $P$. edulis has already undergone plant breeding, which may explain a greater development of its tissues (EMBRAPA, 2005; BELLON et al., 2007).

\section{Conclusion}

The species $P$. edulis showed better responses to the variables of development and leaf morphology.

The species $P$. gibertii is more susceptible to nutrient deficiency and showed changes in the color and shape of its leaves with the restriction of nutrients.

The nutrients $\mathrm{Fe}$ and $\mathrm{Mg}$ caused greater restrictions on the development and leaf morphology of passion fruit species.

It is necessary to carry out a new study with the species $P$. gibertii regarding the appropriate concentrations of $\mathrm{N}, \mathrm{P}$ and $\mathrm{K}$ provided in planting and cover, as this species is used as a rootstock in commercial areas. 


\section{Ethical approval}

This article does not contain any studies with human participants or animals performed by any of the authors.

\section{Declaration of Competing Interest}

Authors declare that they have no conflict of interest.

\section{Reference}

ALMEIDA, E.V.; NATALE, W.; PRADO, R.M.; BARBOSA, J.C. Nitrogen and potassic fertilization on development of passion fruit seedlings. Ciência Rural, v.36, n.4, p.1138-1142, 2006. http://dx.doi.org/10.1590/S0103$\underline{84782006000400015}$

ALSCHER, R.G.; ERTURK, N.; HEATH, L.S. Role of superoxide dismutases (SODs) in controlling oxidative stress in plants. Journal of Experimental Botany, v.53, p.1331-1341, 2002. https://doi.org/10.1093/jexbot/53.372.1331

AMTHOR, J.S.; BAR-EVEN, A.; HANSON, A.D.; MILLAR, A.H.; STITT, M.; SWEETLOVE, S.; TYERMAN, D. Engineering Strategies to Boost Crop Productivity by Cutting Respiratory Carbon Loss. The Plant Cell, v.31, n.2, p.297-314, 2019. http://dx.doi.org/10.1105/tpc.18.00743

BANZATTO, D.A.; KRONKA. S.N. Experimentação Agrícola. 4.ed. Funep, 2013. 237p.

BELLON, G.; FALEIRO, F.G.; JUNQUEIRA, K.P.; JUNQUEIRA, N.T.V.; SANTOS, E.C.; BRAGA, M.F.; GUIMARÃES, C.T. Genetic variability of wild and commercial passion fruit (Passiflora edulis Sims.) accessions using RAPD markers. Revista Brasileira de Fruticultura, v.29, n.1, p.124-127, $2007 . \quad$ https://doi.org/10.1590/S010029452007000100027

CASTRO, E.M.; PEREIRA, F.J.; PAIVA, R. Histologia vegetal: estrutura e função de órgãos vegetativos. Lavras: Universidade Federal de Lavras, 2009. $234 \mathrm{p}$.

EMBRAPA. Maracujá: germoplasma e melhoramento genético. Embrapa Cerrados, 2005. 70p.

FLEISCHER, K.; RAMMIG, A.; KAUWE, M.G.; WALKER, AP.; DOMINGUES, T.F.; FUCHSLUEGER, L.; GARCIA, S.; GOLL, D.S.; GRANDIS, A.; JIANG,
M.; HAVERD, V.; HOFHANSL, F.; HOLM, J.A.; KRUIJT, B.; LEUNG, F.; MEDLYN, B.E.; MERCADO, L.M.; NORBY, R.J.; PAK, B.; RANDOW, C.; QUESADA, C.A.; SCHAAP, K.J.; VALVERDEBARRANTES, O.J.; WANG, Y.; YANG, Y.; ZAEHLE, S.; QING ZHU, Q.; LAPOLA, D.M. Amazon forest response to $\mathrm{CO}_{2}$ fertilization dependent on plant phosphorus acquisition. Nature Geoscience, v.12, p.736-741,

2019. https://doi.org/10.1038/s41561-019-0404-9

FURLANI, P.R. Instruções para o cultivo de hortaliças de folhas pela técnica de Hidroponia NFT. Campinas: Instituto Agronômico, 1998. 30p.

GUO, J.; JIA, Y.; CHEN, H.; ZHANG, L.; YANG, J.; ZHANG, J.; HU, X.; YE, X.; LI, Y.; ZHOU, Y. Growth, photosynthesis, and nutrient uptake in wheat are affected by differences in nitrogen levels and forms and potassium supply. Scientific Reports, v.9, p.1-12, 2019. https://doi.org/10.1038/s41598-018-37838-3

HAM, B.; CHEN, J.; YAN, Y.; LUCAS. W.J. Insights into plant phosphate sensing and signaling. Current Opinion in Biotechnology, v.49, p.1-9, 2018. http://dx.doi.org/10.1016/i.copbio.2017.07.005

KOBAYASHI, T.; NOZOYE, T.; NISHIZAWA, N.K. Iron transport and its regulation in plants. Free Radical Biology and Medicine, v.133, p.11-20, 2019.

https://doi.org/10.1016/j.freeradbiomed.2018.10 $\underline{.439}$

KOCH, M.; BUSSE, M.; NAUMANN, M.; JÁKLI, B.; SMIT, I.; CAKMAK, I.; HERMANS, C.; PAWELZIK, E. Differential effects of varied potassium and magnesium nutrition on production and partitioning of photoassimilates in potato plants. Physiologia Plantarum, v.166, n.4, p.921935, 2019. http://dx.doi.org/10.1111/ppl.12846 MOHOTTI, A.J.; LAWLOR. D.W. Diurnal variation of photosynthesis and photoinhibition in tea: effects of irradiance and nitrogen supply during growth in the field. Journal Experimental Botany, v.53, n.367, p.313-32, 2002. http://dx.doi.org/10.1093/iexbot/53.367.313

PACHECO, A.L.V.; PAGLIARINI, M.F.; FREITAS, G.B.; VIEIRA, G. Yellow passion fruit postharvest conservation and quality according to organic and mineral fertilizer. Revista Brasileira de 
Fruticultura, v.40, n.5, p.1-8, 2018. http://dx.doi.org/10.1590/0100-29452018001

PRADO, R.M.; VALE, D.W.; ROMUALDO. L.M. Phosphorus application to the nutritional status and dry matter production of passion fruit cuttings. Acta Scientiarum Agronomy, v.27, n.3, p.493-498, 2005. In Portuguese https://doi.org/10.4025/actasciagron.v27i3.1461

PRANCKIETIENĖ, I.; DROMANTIENĖ, R.; SMALSTIENE், V.; JODAUGIENE், D.; VAGUSEVIČIENĖ, I.; PAULAUSKIENĖ, A.; MARKS, $M$. Effect of liquid amide nitrogen fertilizer with magnesium and sulphur on spring wheat chlorophyll content, accumulation of nitrogen and yield. Journal of Elementology, v.25, n.1, p.139-150, 2020. http://dx.doi.org/10.5601/jelem.2019.24.2.1742

QIN, L.; WALK, T.C.; HAN, P.; CHEN, L.; ZHANG, S.; LI, Y.; HU, X.; XIE, L.; YANG, Y.; LIU, J.; LU, X.; YU, C.; TIAN, J.; SHAFF, J.E.; KOCHIAN, L.V.; LIAO, X.; LIAO. H. Adaption of roots to nitrogen deficiency revealed by $3 \mathrm{D}$ quantification and proteomic analysis. Plant Physiology, v.179, n.1, p.329-347, 2019. http://dx.doi.org/10.1104/pp.18.00716

$R$ CORE TEAM. R: A language and environment for statistical computing. Vienna: R Foundation for Statistical Computing. 2015. Disponível em https://www.R-project.org/

REIS, A.R.; BARCELOS, J.P.Q.; OSÓRIO, C.R.W.; SANTOS, E.F.; LISBOA, L.A.M.; SANTINI, J.M.K.; SANTOS, M.J.D.; FURLANI JUNIOR, E.; CAMPOS, M.; FIGUEIREDO, P.A.M.; LAVRES, J.; GRATÃO, P.L. A glimpse into the physiological, biochemical and nutritional status of soybean plants under $\mathrm{Ni}$ stress conditions. Environmental and Experimental Botany, v.144, p.76-87, 2017. http://dx.doi.org/10.1016/j.envexpbot.2017.10.0 $\underline{06}$

SAMBORSKA, I.A.; KALAJI, H.M.; SIECZKO, L.; GOLTSEV, V.; BORUCKI, W.; JAJOO, A. Structural and functional disorder in the photosynthetic apparatus of radish plants under magnesium deficiency. Functional Plant Biology, v.45, n.6, p.668-680,

2018.

http://dx.doi.org/10.1071/fp17241

SANTOS, G.P.; CAVALCANTE, L.F.; NASCIMENTO, J.AM.; LIMA NETO, A.J.; MEDEIROS, S.A.S.; CAVALCANTE, I.H.L. Nutritional status of yellow passion fruit fertilized with phosphorus sources and doses. Journal of Soil Science and Plant Nutrition, v.18, n.2, p.388-402, 2018. http://dx.doi.org/10.4067/s0718$\underline{95162018005001204}$

SCHORSCH, M.; KRAMER, M.; GOSS, T.; EISENHUT, M.; ROBINSON, N.; OSMAN, D.; WILDE, A.; SADAF, S.; BRÜCKLER, H.; WALDER, L.; SCHEIBE, R.; HASE, T.; HANKE, G.T. A unique ferredoxin acts as a player in the low-iron response of photosynthetic organisms. Proceedings of the National Academy of Sciences, v.115, n.51, p.12111-12120, 2018. http://dx.doi.org/10.1073/pnas.1810379115

SCHULLER, J.M.; BIRRELL, J.A.; TANAKA, H.; KONUMA, T.; WULFHORST, H.; COX, N.; SCHULLER, S.K.; THIEMANN, J.; LUBITZ, W.; SÉTIF, P.; IKEGAMI, T.; ENGEL, B.D.; KURISU, G.; NOWACZYK, M.M. Structural adaptations of photosynthetic complex I enable ferredoxindependent electron transfer. Science, v.363, n.6424, p.257-260, 2019. http://dx.doi.org/10.1126/science.aau3613

SHAUL, O. Magnesium transport and function in plants: the tip of the iceberg. Biometals, v.15, p.307-321, 2002.

https://doi.org/10.1023/A:1016091118585

SHEN, C.; SHI, X.; XIE, C.; LI, Y.; YANG, H.; MEI, X.; $X U, Y$.; DONG, $C$. The change in microstructure of petioles and peduncles and transporter gene expression by potassium influences the distribution of nutrients and sugars in pear leaves and fruit. Journal of Plant Physiology, v.232, p.320-333, 2019. https://doi.org/10.1016/i.jplph.2018.11.025

SRIVASTAVA, A.K.; A. SHANKAR, A.; CHANDRAN, A.K.N.; SHARMA, M.; JUNG, K.; SUPRASANNA, P.; PANDEY. G.K. Emerging concepts of potassium homeostasis in plants. Journal of Experimental Botany, v.71, n.2, p.608-619, 2020. https://doi.org/10.1093/jxb/erz458

STEWART, J.J.; POLUTCHKO, S.K.; ADAMS, W.W.; COHU, C.M.; WENZL, C.A.; DEMMIG-ADAMS, B. Light, temperature and tocopherol status influence foliar vascular anatomy and leaf function in Arabidopsis thaliana. Physiologia Plantarum, v.160, n.1, p.98-110, 2017. http://dx.doi.org/10.1111/ppl.12543 
TAIZ, L.; ZEIGER. E. Fisiologia vegetal. 5. ed. Porto Alegre: Artmed, 2013. 918p.

WANG, F.; DENG, M.; XU, J.; ZHU, X.; MAO, C. Molecular mechanisms of phosphate transport and signaling in higher plants. Seminars in Cell \& Developmental Biology, v.74, p.114-122, 2018. http://dx.doi.org/10.1016/i.semcdb.2017.06.013

WANG, Y.; GONG, Z.; FRIML, J.; ZHANG. J. Nitrate modulates the differentiation of root distal stem cells. Plant Physiology, v.180, n.1, p.22-25, 2019. http://dx.doi.org/10.1104/pp.18.01305

WOLDEMARIAM, S.H.; LAL, S.; ZELELEW, D.Z.; SOLOMON, M.T. Effect of potassium levels on productivity and fruit quality of tomato (Lycopersicon esculentum L.). Journal of Agricultural Studies, v. 6, n.1, p.102-115, 2018. http://dx.doi.org/10.5296/jas.v6i1.12262

ZHANG, X.; WU, H.; CHEN, L.; WANG, N.; WEI, C.; WAN, $X$. Mesophyll cells' ability to maintain potassium is correlated with drought tolerance in tea (Camellia sinensis). Plant Physiology and Biochemistry, v.136, p.196-203, 2019. https://doi.org/10.1016/i.plaphy.2019.01.020 